\title{
DON QUIXOTE AND THE LIAR'S PARADOX
}

“I AM LYING." IT MIGHT BE SAID THAT THIS STATEMENT IS, IMPLICITLY, THE SINGLE REAL TRUTH OF THE FICTION-FORMING AUTHOR, AND ITS COMPLICATIONS ARE BOTH THE EMBLEM AND BANE OF ALL NOVELS. IN HIS EPIC DON QUIXOTE, MIGUEL DE CERVANTES EXPLOITS THE PROBLEM OF MAKING LIES REAL BY INTRICATELY WEAVING TOGETHER SUCH DISPARATE ELEMENTS AS AUTOBIOGRAPHYAND HIGH FANTASY WITHIN THE UNRELIABLY UNRELIABLE VOICES OF SEVERAL SUBJECTIVE STORYTELLERS. AND HIS CONCLUSION, IT SEEMS, IS DON QUIXOTE HIMSELF, A MAN WHO COMBATS THE PROTEAN STRANGENESS OF THE WORLD BYREPLACING IT WITHA DELIBERATEREALITY OF HIS OWN. AT THE CUSP OF THE EUROPEAN RENAISSANCE, CERVANTES' DON QUIXOTE MAKES THE CHOICE WHICH WILLBECOMEA NECESSITY FOR POST-CARTESIAN THINKERS, NAMELY, A PERSONAL DETERMINATION, AN AUTHORSHIP OF" THE REAL" IN A WORLD WHERE INCONSISTENCIES AND SUBJECTIVITIES CONSTANTLY THREATEN TO CHAIN THE TRUTH-SEEKING MAN, LIKE PROMETHEUS, TO THE CONFUSION OF THE LIAR'S PARADOX. 


\section{"In a literary work, is reality secreted or is reality secreted?"}

In the late twentieth century two sociologists, Bruno Latour and Steve Woolgar, spent several months in an eventually Nobel Prize-winning biology laboratory in an attempt to study how scientists' social interactions construct the reality which their science purports. The conclusion from the study was a seemingly simple one: "Reality is secreted." $\mathrm{i}$ Their intended implication was that the fact of science is as much authored as fiction, but curiosity provokes the question, what if this idea is applied to actual, acknowledged fiction? In a literary work, is reality secreted or is reality secreted?

Miguel de Cervantes' Don Quixote de la Mancha is "the child of [his] brain" (I5), a masterwork of fiction that laces together an unprecedented tapestry of these two aspects, both secreted and secreted reality. As such, it is an emblem of a great conundrum of humanity and the especial fascination of the European Renaissance, the problem of reality and fiction.

I.

I think of cinemas, panoramic sleights

With multitudes bent toward some flashing scene

Never disclosed, but hastened to again,

Foretold to other eyes on the same screen. $i i$

Centuries before Pirandello's Six Characters in Search of an Author, Don Quixote first introduced the problem of reality and fiction through ambiguity of authorship. Its narrative consists of a diagram-worthy lineage, beginning (or ending) with Cervantes himself and following to the book's narrator, who claims to learn his story from several sources but mostly (from I:9 on) through the further remove of a Castilian translation of Cid Hamet ben Engeli's Moorish chronicle. It is worth noting, too, that al-

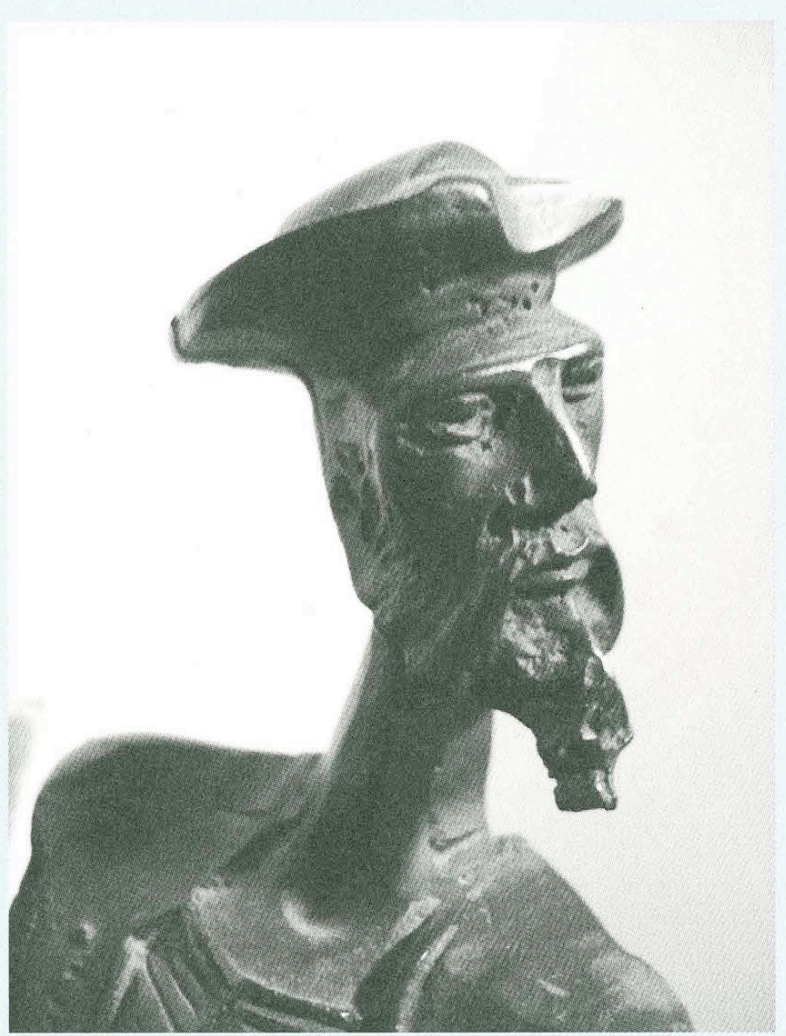

though Cervantes' Spanish text does exist, many an American reader is obliged to encounter it through an English translation. ${ }^{\text {iii }}$

Don Quixote's authorial lineage is porous as a sponge and saturated with equivocations that combine to drown out any concept of "truth." At the base is straightforward authorial suspicion: although Ben Engeli is a self-designated "Arabian historiographer" and the narrator says that "historians ought to be precise, faithful, and unprejudiced," by the next page he, himself a historian, voices his own prejudice that "the author was an Arab, those of that nation being 
not a little addicted to lying" (68-69). Ben Engeli, for his own part, readily admits his plethora of sources - including other historians, hearsay and his own opinions - further complicating the quest for an Ur-text of Don Quixote's story. The unreliability of the chronicle is enough to confuse even the identities of the characters themselves: Sancho introduces himself as "Sancho Panza, am I, unless I was changed in the cradle, I mean the press" (663).

Such interaction between different levels of the authorial lineage form the supreme complication of Don Quixote's telling. Ben Engeli's omniscience poses a problem because it is not merely a device of fiction; Sancho and Don Quixote are aware of his omniscience and wonder "how the historian who wrote [the book], could come to know" of "things which passed between [them] only" (483). Although this might lead the reader to posit "Ben Engeli" as a penname for Don Quixote (or Sancho), the fact that neither character gives any hint of authorship and further, that Ben Engeli at times states his own judgment and conjectures because he

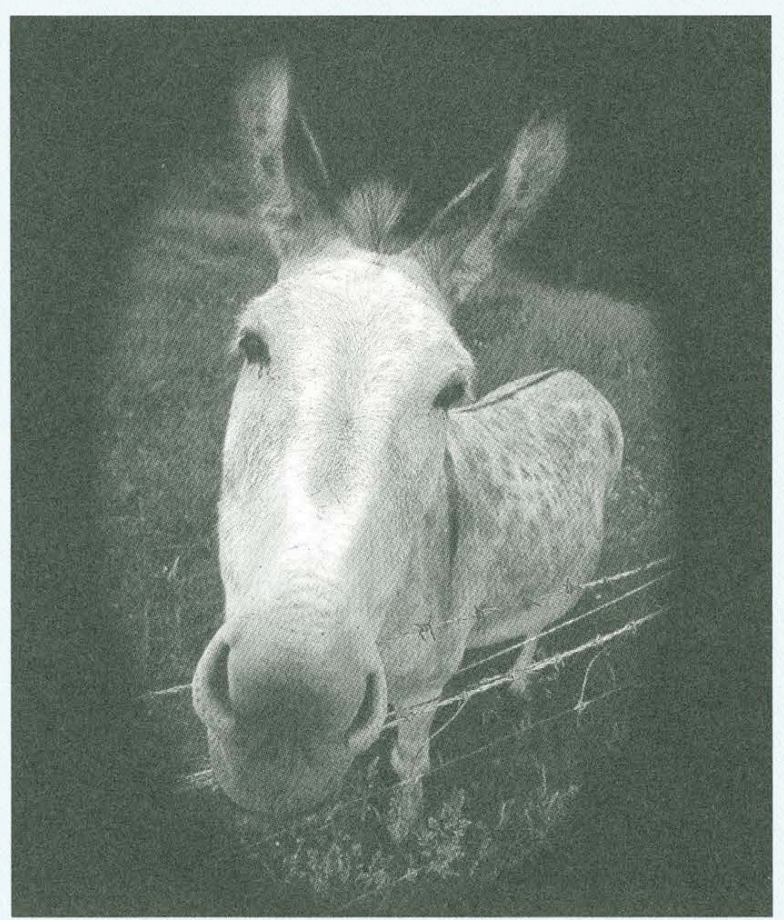

lacks knowledge of the story's details (cf. the name of "Barataria" on 753), proves otherwise. Thus, Ben Engeli's tale seems neither completely autobiography-worthy truth nor fully-fashioned fiction, and in Pascal's words, its imagination is "all the more deceptive for not being invariably so." iv As the characters' consciousness "infiltrates" every level of authorship (except for that of the primary narrator), even Cervantes' identity is complicated by the priest's citation of him as "a great friend" whose Galatea is in Don Quixote's library (53). This meta-confusion gives us a firsthand insight into how the inherent, inescapable blurring of fiction and reality in "foolish books" is enough to instigate the madness of that "unhappy gentleman," Don Quixote (262). Further, it proves problematic for us as well, because though we "cannot persuade [ourselves] it is a true story: and if it be a fiction, the author has erred against probability: for it cannot be imagined, [...] there is something impossible to it" (32I). As Pascal says, such fiction "would be an infallible criterion of truth if it were infallibly that of lies. Since, however, it is usually false, it gives no indication of its quality, setting the same mark on true and false alike."v

II.

Much madness is divinest sense

To a discerning eye;

Much sense the starkest madness.

' $T$ is the majority

In this, as all, prevails.

Assent, and you are sane;

Demur,-you're straightway dangerous,

And handled with a chain. vi

However we might believe his various authors, the deepest fissure of complication splits open when we address the authorship of Don Quixote's self. Is he truly, unconsciously mad, the product of the "inventions and lies" and the "style and manner of his foolish books" (262)? Or is he genuinely sane and the author of his own mind, a knight whose "profession [...] requires [him] to understand everything" (204), even what the seemingly-sane cannot understand? 
To claim Don Quixote as mad, we would require some contextual measure for sanity. Yet we can only call his madness relative - he is "but mad north-north-west" - for his Castle Ellsinore is peopled by characters of such questionable sanity that they must not only distrust "all that the enamoured poets tell [them] for truth" (300), but distrust their very selves. Cid Hamet avers that "the mockers [of Don Quixote] were as mad as the mocked; and that the duke and duchess were within two fingers' breadth of appearing to be mad themselves, since they took so much pains to make a jest of two fools" (9I9). Tom Cecial points out to Sampson Carrasco, "Don Quixote is mad and we think ourselves wise: he gets off sound and laughing, and your worship remains sore and sorrowful. Now, pray, which is the greatest madman, he who is so because he cannot help it, or he who is so on purpose?" (560).

In such a world where all sense of sanity is relative, Don Quixote's only recourse is to create a system of sanity in which he can live himself; where reality is secreted, he secretes his own reality. Though this may make him seem conventionally mad, his reality is of no more or less verity than the "reality" that is assumed by others, and indeed it may be worth more, as it at least allows Quixote to trust in something within the "Cave of Montesinos" that is the apparent world. Unlike others, Don Quixote can claim that "the coherent discourse I made to myself, convinced me, that I was then and there the same person I am now here" and not some "empty and counterfeit illusion" (6I4). And unlike others who have "done amiss in suffering [themselves] to be carried away by the current of those, who take it for granted [chivalric stories] are not true" (564), Quixote at least chooses his own beliefs.

Thus, Don Quixote forsakes the search for reality in favor of the creation of contentedness. He evades the "unexpected accidents" that "perpetually befall those who live in this miserable world" (824) by recasting them as "enchantments." As a self-made knight, he is "able to penetrate into the designs of the enemy, to form stratagems, overcome difficulties, and prevent dangers which threaten: for all of these things are acts of the understanding" (338). When faced with adversity, he must merely turn to the self that he has created and say, "In truth [the situation] is so frightful, that, were I not who I am, I should be afraid myself" (555).

By the end of his story, Don Quixote's method of realityconstruction (Latour and Woolgar would call it "agonistic" activityvii) has spread to others, including the duke and duchess, who, "having executed their design so ingeniously and happily," realize that "nothing real could have afforded them more pleasure" (703). In the end, the world's chosen reality becomes the "madness" of Don Quixote himself. Don Alvaro Tarfe, for one, negates the reality of his own self - he becomes "persuaded he must needs be enchanted" (932) - in favor of believing the self-asserted reality of Ben Engeli's Don Quixote. Further, Don Antonio admonishes Sampson Carrasco for "the injury [he has] done the whole world" in "endeavoring to restore to his senses the most diverting madman in it." By the end of Don Quixote, it might be said that the reader and even Cervantes are ready to proclaim with Don Antonio: "May Don Quixote never be recovered!"viii (895).

\section{I.}

I no longer strive to strive towards such things

(Why should the agèd eagle stretch its wings?)

Why should I mourn

The vanished power of the usual reign?ix

Don Quixote is an emblematic work of the Renaissance because the agnostic method which facilitates Don Quixote's mad, self-created "reality" becomes the relief, liberation, and final recourse of an era which, in emerging from the medieval religious tradition, must discover a new opiate. Thus, Renaissance literature is marked by the intellectuality of reality-construction, at first as a necessary remedy to the human being's inability to understand or derive certain happiness from the apparent "reality," and later as the only option when "reality" is defined by Descartes as defined solely by the human mind. 
Of any Renaissance literature, William Shakespeare's plays best represent the progression from the insufficiency of apparent "reality" to a compensatory reality-construction. Richard II (I595) ${ }^{\mathrm{x}}$ presents the king as at the mercy of his situation's supposed reality which he assumes is beyond his control. He tries in the "Pomfret Castle soliloquy" (V.v) to make his "brain [...] the female to [his] soul" yet he generates only "still-breeding thoughts"; "no thought is contented" because he fails to prepare a womb, a world in which to construct his mind. The "hard world" and its "rugged prison walls" still exist for him as fact, and they preclude self-mastery, leaving his thoughts only to "flatter themselves | That they are not the first of fortune's slaves." In King John (1596), Shakespeare implies a hope for Richard if only he could attain it: cries grief-stricken Constance, "I am not mad; - I would to heaven I were! [...] too well, too well, I feel | The different plague of each calamity" (III.iv). In Hamlet (I600), the prince partially actualizes this idea. Hamlet "put[s] an antic disposition on" (I.v), indeed, yet he fails to find relief in his madness-altered reality because he does not believe it. Still on his mind is the absolute of "is" ("To be, or not to be") that arms him against "outrageous fortune" and "the thousand natural shocks | That flesh is heir to" (III.i) only with death (an out for which King Richard ultimately opts). xi

Shakespeare's great change of his characters' minds comes with King Lear (1605), where several characters set out to fight nature by their art of reality-construction. Here, "the excellent foppery of the world" and the "admirable evasion of whoremaster man" is acknowledged so that "fortune," which is "often the surfeit of our own behaviour," may no longer be allowed to excuse "villains by necessity; fools by heavenly compulsion" (I.ii). Lear appears mad as he first radically alters the custom of primogeniture and posthumous inheritance and then, when the "reality" becomes that his premature-heiresses forsake him, he has the satisfaction of condemning them in an imaginary court of law. Edmund, for his part, seems not mad but devious in his "invention" of a world where the gods might change the reality of birthright and "stand up for bastards" (I.ii). Like Don
Quixote's duke and duchess, Edmund consciously flouts the nonexistent rules of the universe to construct the reality that he desires. Though Shakespeare is the final decider of their destiny, Lear and Edmund both strive to fare better along the path to tragedy by achieving not only self-construction but world-construction.

Through all of this, though, the question nags: what if Don Quixote is ultimately right, and "art cannot exceed nature" (568)? What if the secreted reality cannot be fully or wholeheartedly replaced? Constance claims, "I have reason to be fond of grief" because it seems that "Grief fills the room up of my absent child, | Lies in his bed, walks up and down with me, | Puts on his pretty looks, repeats his words, | Remembers me of all his gracious parts, I Stuffs out his vacant garments with his form" (III.iv). Thus, self-inflicted "reason" yokes her to an insufficient "reality," almost identical to that of Jan Kochanowski in his Laments. Kochanowski, for his part, does attempt the agonistic approach by deifying and devoting himself to "Wisdom," yet such an approach leaves him unconsoled, and he is "hurled, like all the rest, from the topmost stair" ("Tren 9"). Yet if he made the effort, why does his secreted reality fail?

IV.

Everything I say is a lie...except that... and that...

and that, and that, andthatandthatandthat...and... xii

The failure of reality-construction is revealed in Kochanowski as it proceeds from the intrusion of the liar's paradox, the self-defeat of perpetual disbelief that Pascal cites in his criticism of skeptics. xiii Such is the problem that complicates the fictionality of Don Quixote both within the tangled lineage of authorship and the uncertainty of Quixote's madness, and such is the problem that makes such construction-attempts as Quixote's, Lear's, and Kochanowski's ultimately unsuccessful in achieving happiness. At some point the rules set out by a self-constructed reality - a reality created in deliberate disbelief of the apparent "reality" - will either be disbelieved themselves (in the case of Kochanowski) or will be so fully believed that they 
trip the constructionist right back into slavery of an apparent "reality." Like Don Quixote, the intellectual is brought into "so many disadventures" that he does "not know which is [his] right foot" (126) but that it is shackled to his self-created fate. This outcome is the case for Lear, as his inheritance-scheme backfires by his daughters' ingratitude and cruelty, and also for Don Quixote, as chivalry finally requires him to surrender to Sampson Carrasco and end his career as a knight-errant.

The failure of agnosticism leaves the Renaissance with one of its greatest quandaries. By the time of Descartes' "cogito," such declarations as Montaigne's "Nature always gives us happier laws than those we give ourselves" cannot be adopted as resolutions because no two views of nature (the apparent "reality") are the same. Man seems doomed to Jansenism's sentence of "subterranean conduct" regardless of whether he has "supercelestial thoughts" or no, because "[j] ustice and truth," the bases of happiness, "are two points so fine that our instruments are too blunt to touch them exactly."xiv In short, reality-construction becomes not only a remedy but an inevitability. Kochanowski defines the problem in "Tren I": "What is not vain, by God, in lives of men?”

\section{"In short, reality-construction becomes not only a remedy but an inevitability."}

Yet the key to the Renaissance's resolution hides at the center of this. After the melancholia of the intellectual agonistic and after the failure of Panglossially-optimistic "reason, the sport of every wind, "xv there is faith and there is God. The difference between the Renaissance's choice of faith to that of the medieval tradition, though, is that faith cannot be taken on faith alone. Faith's obstacle is that, like Milton's Satan, we "novel, $[\ldots]$ monstrous, $[\ldots]$ chaotic, $[\ldots]$ paradoxi- cal, [and] prodigious"xvi humans find that our "wonted pride" and "proud imaginations" persuade us that we can "seek | Our own good from ourselves." Our "[v]ain wisdom" excites the "[f]allacious hope" that "[a]s [God provides] our darkness, cannot we his Light | Imitate when we please?" The snag is that we and our constructed world "ill become this Throne"xyii of wisdom, and like Satan and Kochanowski, we soon tumble "from the topmost stair."

The consequence of our prideful intellectuality is that we are left little better than melancholy Hamlet, saddled either with Satan's choice "rather than be less, [...] not to be at all" or the implied alternative - "to be." Yet how can we happily "be" when we cannot sustain an agonistic, when (in Wallace Stevens' words) we cannot "be one thing and be it long"?xviii As Pascal will tell us, we "must wager;" we must gamble on whether to stake our reality-construction in God and, concomitantly, on whether to have faith. Laid on the betting table are life's little trivialities: "the true and the good [...] [our] reason and [our] will, [our] knowledge and [our] happiness." xix

In wagering for faith, we must realize that, because invisible faith trumps more tangible forms of salvation in the post-Lutheran Renaissance, we are merely choosing another agonistic; such a choice is inescapable, for "[c]ustom" - abidance to a created reality - "is our nature." Yet in this wager "there is an infinity of infinitely happy life to be won," and even if we can never know truth, we can recognize Don Quixote's claim that "where truth is, there God himself is, so far as truth is concerned" (489), and as Pascal adds, "if men are capable of any truth this is it."xx What remains, then, is to put this newly adopted reality of faith to the test and find whether it provides the happiness which eludes all other intellectual constructions. Are we "yet happiest if [we] seek | No happier state, and know to know no more" ?xxi The resounding answer, at least in the literature of the Renaissance, is "Yes."

The affirmation of a reality of faith comes from all quarters. Kochanowski finally asks himself "Why is your mind a 
burning candlewick | Wasting itself?" then consents to the reality that " $[\mathrm{t}]$ he Lord's ways are not ours. | Our task is simply to accord with them" and "try to live on | Consoled by changeless heaven's certainty" ("Tren ig albo: Sen"). In King Lear, Gloster gives over his "proud will" and believes his life has been saved by "the clearest gods, who make them honours | Of men's impossibilities” (IV.vi). With such reassurance, he then dies peacefully as his "flaw'd heart | 'Twixt two extremes of passion, joy and grief, | Burst[s] smilingly" (V.iii). Lear, for his part, finally dies calling "Look there, look there," leaving us to wonder whether he has seen truth or God or both, but unequivocally leaving us with a better "inheritance" in the recognition that he has had some spiritual vision (V.iii).xxii

Don Quixote, though, offers the paragon of affirmations. Sancho, who like so many other characters (fictional and otherwise) has been wooed to the trust of Don Quixote's "mad" reality, argues fervently with his master that "the greatest madness a man can commit in this life is to suffer himself to die, without [...] being brought to his end by any other hand than that of melancholyxxii" (94I). Unfortunately for Sancho, though, his pleas fall on changed ears. Don Quixote - now "Alonso Quixano" - renounces his previous "folly" through "the mercy of God," (940) and dies "in so composed and Christian a manner" that the notary does not recognize him for a knight-errant (943).

Thus, choosing faith over his intellectual melancholy, Cid Hamet ben Engeli's "true and genuine Don Quixote" (944) exits the final world which he has created. With him departs the chance of innocently following an intellectual agonistic scheme of reality-construction. Yet what he bequeaths to us is a distinctly Renaissancian nuance in the tradition of faith; whether or not God's supremacy is the true secreted reality, insofar as secreted realities are our only recourse, it is still the most fulfilling. After all of our intellectual pursuits, we must "descend now therefore from this top | Of Speculation" and simply begin to "cultivate our gardens."xxiv

\section{ENDNOTES}

i Latour and Woolgar, 206.

ii Crane, Hart. "Proem: To Brooklyn Bridge." The Complete Poems of Hart Crane: Centennial Edition. Ed. Marc Simon.

New York: Liveright, $200 \mathrm{I}$.

iii Such as that of Charles Jarvis, from whose edition I will quote Don Quixote.

v Ibid. [Italics are my own.]

vi Dickinson, Emily. "XI." Emily Dickinson: The Complete

Poems. Boston: Little, Brown, 1924. Quoted from

<http://www.bartleby.com/I13/IoII.html>. New York:

Bartleby.com, 2000.

vii The "agonistic field" is where "reality is the consequence rather than the cause of this construction." p. 204

viii Is the translator speaking here merely about healing Don Quixote's sanity or finding his character? The wordplay exists in English, however in Spanish the verb is sanar, which means "recover" exclusively in the connotation of "healing" [not "finding"]. Don Quijote de la Mancha.

<http://www.intratext.com/IXT/ESL0027>. Intratext/Eulogos, 2002.

ix Eliot, T.S. "Ash Wednesday." Collected Poems: Ig09-Ig62. New York: Harcourt Brace, 1991.

$\mathrm{x}$ These dates are of the believed first performance.

$<$ http://www.shakespeare-

online.com/keydates/playchron.html>.

xi I am indebted in the selection of these three plays to Stephen Greenblatt's essay "The Death of Hamnet and the Making of Hamlet."

xii "Episode I5: Save the Children." Family Guy.

xiii Pascal, 34

xiv Montaigne, 107 and 135; Pascal. p. I2.

xv Pascal. p. 10.

xvi Pascal. p. 34 .

xvii Milton, 2I, 30, 37, 45, 37, and 42, respectively.

xviii Milton. p. 3I. Stevens is quoted from "The Comedian as the Letter C."

xix Pascal. p. I23.

xx Pascal. p. 125, 123, and 124, respectively.

xxi Milton. p. 106.

xxii "With a sudden intensity, as if she saw it clear for a second, she drew a line there, in the centre. It was done; it was finished. Yes, she thought, laying down her brush in extreme fatigue, I have had my vision." Woolf, Virginia. To the Lighthouse. xxiii The Spanish word here is indeed "melancholía." Thus, we can legitimately relate the text to Albrecht Dürer's depiction of deep intellectual melancholy in his woodcut "Melencolia I." It is followed in Dürer's sequence by "St. Jerome in his Study," a work depicting the acceptance of the human lot through faith. xxiv Milton, 306. Voltaire,. 328 . 


\section{REFERENCES}

Cervantes, Miguel de. Don Quixote. Trans. Charles Jarvis. New York: Oxford University Press, I992.

Don Quijote de la Mancha..

<http://www.intratext.com/IXT/ESL0027>. Intratext/Eulogos, 2002

Greenblatt, Stephen, "The Death of Hamnet and the Making of Hamlet." The New York Times Review of Books. 2I October 2004, Vol. 5I, No. I6.

Latour and Woolgar. "The Social Construction of Scientific Facts." Readings in the Philosophy of Science: From Positivism to Postmodernism. Ed. Theodore Schick. New York: McGrawHill, I999.

Milton, John. Paradise Lost. Ed. Merritt Y. Hughes. New York: Odyssey Press, I962.

Montaigne, Michel. Selections from the Essays. Ed. and transl. Donald M. Frame. Arlington Heights, Ill: : Harlan Davidson, I973.

Pascal, Blaise. Pensées. Transl. A.J. Krailsheimer. New York: Penguin Putnam, I995.

Voltaire. Candide. The Portable Voltaire. Ed. Ben Ray Redman. New York: Penguin, I977. 